\title{
Association of a Phloem-Limited Bacterium with Yellow Vine Disease in Cucurbits
}

\author{
B. D. Bruton, United States Department of Agriculture, Agricultural Research Service (USDA-ARS), Lane, Okla- \\ homa 74555; J. Fletcher, Department of Plant Pathology, Oklahoma State University, Stillwater 74078; S. D. Pair, \\ USDA-ARS; M. Shaw, Department of Plant Pathology, Oklahoma State University; H. Sittertz-Bhatkar, Electron \\ Microscopy Center, Texas A\&M University, College Station 77843
}

\begin{abstract}
Bruton, B. D., Fletcher, J., Pair, S. D., Shaw, M., and Sittertz-Bhatkar, H. 1998. Association of a phloem-limited bacterium with yellow vine disease in cucurbits. Plant Dis. 82:512-520.

Since 1991, a new disease of cucurbits in central Texas and Oklahoma, designated yellow vine, has resulted in the decline and plant death of watermelon, cantaloupe, squash, and pumpkin. Affected plants are characterized by leaf yellowing, phloem discoloration, and plant collapse. Year-to-year variation in disease incidence has ranged from spotty outbreaks to complete crop loss in early-planted watermelon fields. A systematic investigation to determine the causal agent of the disease included pathogen isolation attempts, transmission tests, serological assays with various antisera (enzyme-linked immunosorbent assay and Western blotting), and DNA hybridizations with selected probes (dot and Southern blots). None of these tests revealed a consistent relationship between the expression of yellow vine symptoms and the presence of a particular microorganism or virus in the plant. However, transmission electron microscopic examination showed the consistent presence of a bacterium in the phloem sieve elements of symptomatic plants. The rod-shaped bacteria, observed only in symptomatic cucurbits, measured 0.25 to 0.5 $\mu \mathrm{m}$ in width and 1.0 to $3.0 \mu \mathrm{m}$ in length and were surrounded by a triple-layered cell envelope.
\end{abstract}

Additional keywords: Citrullus lanatus, Cucumis melo, Cucurbita spp., insect, vine decline

Cucurbits are major horticultural crops in Texas and Oklahoma, accounting for approximately 40,000 ha and an annual value greater than $\$ 100$ million dollars $(\mathrm{F}$. Dainello and J. Motes, personal communication). Vine declines of cucurbits have increased in number and severity in the past 20 years and are a yield-limiting factor in many intensive production areas around the world. There are many pathogens capable of producing vine decline symptoms in cucurbits $(5,6)$. Although vine decline symptoms caused by different pathogens are often similar, there are subtle differences (9). In 1988, a disease of squash (Cucurbita pepo L.) and pumpkin (C. pepo L.) called yellow vine was observed in Central Texas and Oklahoma (7). Yellow vine was first observed in watermelon (Citrullus lanatas (Thunb.) Matsum. \&

Corresponding author: B. D. Bruton

E-mail: bbruton-usda@lane-ag.org

Mention of a trademark, proprietary product, or vendor does not constitute a guarantee or warranty of the product by the USDA and does not imply its approval to the exclusion of other products of vendors that may also be suitable.

Accepted for publication 29 January 1998.

Publication no. D-1998-0309-03R

This article is in the public domain and not copyrightable. It may be freely reprinted with customary crediting of the source. The American Phytopathological Society, 1998.
Nakai) fields near Rush Springs, Oklahoma in 1991. Some fields were a total loss, with all the vines appearing blighted. Other fields in the area exhibited vine yellowing in small patches. Additional surveys near Ryan and Terral, Oklahoma, and near Charlie, Montague, DeLeon, Comanche, and Gustine, Texas revealed that the disease was widespread in the watermelon production area. In addition, squash fields near Charlie, Texas and cantaloupe (Cucumis melo var. cantaloupensis Naud.) fields in DeLeon, Comanche, and Gustine, Texas exhibited similar symptoms of plant yellowing and collapse. The symptom most consistent with the disease in all three plant species was a honey-brown discoloration of the phloem. Root rot was not observed on plants in the early stages of disease development. The purpose of this research was to determine the etiology of this new disease of cantaloupe, squash, pumpkin, and watermelon.

\section{MATERIALS AND METHODS}

Isolation of fungi. Cantaloupe and watermelon plants at various stages of symptom development and asymptomatic plants were collected from fields in the affected areas during the growing seasons of 1991 to 1995. More than 1,000 isolation attempts were made over a 5-year period. Stem and root segments were surface disinfested in $0.5 \% \mathrm{NaOCl}$ and placed on potato dextrose agar (PDA), 2\% water agar plus $0.1 \mathrm{~g} /$ liter streptomycin sulfate, or both. Isolations were normally made $5 \mathrm{~cm}$ above the soil line, at soil line, $5 \mathrm{~cm}$ below soil line, from the primary root, and from the secondary roots, with an emphasis on lesions when present. Plates were examined for fungal growth daily for 5 days, and hyphal tips of each colony were transferred to PDA and Synthetischer nährstoffärmer agar (SNA; 34) and allowed to sporulate. Non-sporulating cultures were kept for 30 to 45 days before being discarded. A minimum of 25 isolates of Fusarium oxysporum Schlechtend.:Fr. emend. W. C. Snyder \& H. N. Hans. obtained from watermelon and cantaloupe were tested for pathogenicity according to the method of Martyn and Bruton (32). Additional Fusarium spp. frequently isolated were tested under greenhouse conditions for pathogenicity by incorporating $10,000 \mathrm{CFU} / \mathrm{g}$ soil in plastic pots (14.5 by $11.0 \mathrm{~cm}$ ). The fungi tested included $F$. solani (Mart.) Appel \& Wollenweb. emend. W. C. Snyder \& H. N. Hans., F. equiseti (Corda) Sacc. sensu Gordon, and F. semitectum Berk. \& Ravenel. The plants were maintained in the greenhouse for 60 days for symptom development.

Isolation of prokaryotes. Stem and root segments of symptomatic and asymptomatic watermelon, cantaloupe, and squash plants, as previously described, were washed in tap water, and 2-mm pieces were surface disinfested for $1 \mathrm{~min}$ in $0.5 \%$ $\mathrm{NaOCl}$ and plated on PDA or nutrient agar (NA). Representative bacteria were singlecell cloned by dilution plating and identified by fatty acid profile analysis (R. Stall, University of Florida and L. Barnes, Texas A\&M University) as described by Wells et al. (43). The bacterial isolates, grown on $\mathrm{NA}$, were syringe inoculated at $1 \times 10^{6}$ cells $/ \mathrm{ml}$ into the lower stems of 10 watermelon and squash seedlings per isolate; a similar number of seedlings received only sterile water. The plants were maintained in the greenhouse for 60 days for symptom development. Two additional agar media, PW (12) and PD2 (14), developed for isolation of the xylem restricted bacterium Xylella fastidiosa, also were used. Isolation attempts for spiroplasmas were as described by Fletcher et al. (21).

Dienes' stain. Sections were removed from roots, crown, stems, and petioles of field-collected symptomatic and asymptomatic watermelon, cantaloupe, squash, and pumpkin plants. Other samples included 
root or stem sections of pepper, sugar beet, and bean plants infected with beet curly top virus (provided by Peter Thomas, United States Department of Agriculture, Agricultural Research Service [USDAARS], Pullman, WA). Staining was performed as described by Deely et al. (17).

Transmission experiments. Terminal shoots (10 to $15 \mathrm{~cm}$ long) of symptomatic and asymptomatic watermelon and squash plants were ground by mortar and pestle using $1 \mathrm{~g}$ fresh weight $/ \mathrm{ml}$ phosphate buffer, $\mathrm{pH}$ 7.2. Test plants (20 each) of cantaloupe, watermelon, and squash at the 3 to 5 true leaf stage were dusted with Carborundum and inoculated mechanically or by the artist-air-brush technique described by Toler and Hebert (42).

Dodder (Cuscuta sp.) was introduced first to healthy periwinkle seedlings (10 to $15 \mathrm{~cm}$ tall) and allowed to establish haustoria. Dodder-infected periwinkle plants (in pots) were then placed adjacent to watermelon plants in the field. A minimum of 25 symptomatic watermelon plants, in the initial stage of disease development, and 25 asymptomatic plants were exposed in this manner. The dodder strands were wrapped around the watermelon runners, with additional runners placed in the vicinity of the dodder-infected periwinkle plants. The periwinkle plants were removed after 2 to 3 weeks and placed in the greenhouse for 60 days for symptom development.

In July and August 1991, insects were collected using sweep nets in fields of watermelon and squash with symptomatic plants. Additional collections were made from bermuda grass around the perimeter of the fields and from plots of onions growing adjacent to the cucurbit crops. Leafhoppers (Homoptera: Cicadellidae) were selected from the nets and the remaining insects were discarded. Insects collected represented the leafhopper subfamilies Agallinae, Cicadellinae, Deltacephalinae, and Typhlocybinae. Most are primarily phloem-feeders, except for the cicadelline leafhoppers, which typically feed in xylem. Some species of Typhlocybinae leafhoppers feed on mesophyll tissue; however, the species involved here were identified only as Empoasca sp. Leafhoppers were separated into their respective subfamily groupings and caged (5 leafhoppers/cage and 4 to 6 cages/group) on seedling periwinkle plants for a 1-week inoculation period in a greenhouse. At the end of the access period, all insects were collected and frozen for later identification. Periwinkle plants exposed to leafhoppers were monitored for symptom development and compared with unexposed control plants for 2 months.

Several attempts were made to transmit a putative pathogen to greenhouse-grown plants using healthy, laboratory-reared leafhoppers. For these tests, the beet leafhopper, Circulifer tenellus, a vector of beet curly top virus and Spiroplasma citri, and the aster leafhopper, Macrosteles quadrilineatus, a vector of the aster yellows phytoplasma, were selected. Both of these Deltacephaline species are phloem-feeders on a variety of plant species. Approximately $100 C$. tenellus or M. quadrilineatus adults and nymphs were allowed to feed on "bouquets" of symptomatic squash cuttings for 2 days in a greenhouse. Turnip plants were added to the cages with $C$. tenellus and barley plants were added to cages containing $M$. quadrilineatus to sustain the insects. Squash vines remained accessible to the insects until the cuttings died. After a 3-week incubation period, 1 aster and 1 periwinkle seedling were placed in each cage and the maintenance plants were removed. Following a 2-week inoculation access period, the test plants were sprayed with resmethrin to kill any remaining insects and were monitored for 2.5 months for symptom development.

In another test, vines from symptomatic watermelon plants were used as the acquisition source. Leafhopper adults and nymphs (approximately 150 each) of $C$. tenellus and $M$. quadrilneatus were caged on bouquets as described above. After a 4day acquisition period, 1 sugar beet seedling was placed in the cage with the $C$. tenellus and 3 aster seedlings were added to the cage with $M$. quadrilineatus. Surviving leafhoppers were removed after 24 days and caged in groups of 5 on single, healthy periwinkle plants. Periwinkle plants were sprayed with resmethrin after 1 week and held for observation for 6 weeks. Control periwinkles were caged with insects not exposed to symptomatic plants.

To further test the ability of $C$. tenellus to transmit an infectious agent to squash, 50 adult leafhoppers were fed for $24 \mathrm{~h}$ on symptomatic field-collected watermelon vines. Leafhoppers were then transferred to the greenhouse in groups of 5 to single sugar beet seedlings for a 2-day inoculation access period. The leafhoppers were then transferred (in three groups of 12) to single squash seedlings. Squash plants were sprayed with resmethrin after 1 week and monitored for symptom development for 6 weeks. Controls consisted of unexposed $C$. tenellus caged with healthy sugar beet and squash plants from the same planting date that were also sprayed and observed as described above.

Enzyme-linked immunosorbent assay. Enzyme-linked immunosorbent assay (ELISA), as modified by Fletcher and Eastman (20) from Clark and Adams (10), was used to test cucurbit samples for the presence of beet curly top virus (BCTV), lettuce infectious yellows virus (LIYV), $S$. citri, and S. kunkelii. The BCTV assays were performed by P. Thomas (USDAARS). Polyclonal antiserum for LIYV was provided by J. K. Brown (Arizona State University), and polyclonal antisera for $S$. citri and S. kunkelii were prepared as de- scribed by Fletcher and Eastman (20) and Gussie et al. (24), respectively. In each case, positive and negative controls consisted of plants inoculated with the pathogen and healthy greenhouse-grown plants, respectively.

Polyacrylamide gel electrophoresis and Western blotting. Symptomatic and asymptomatic cucurbit leaves and stems were homogenized with a mortar and pestle in Tris-buffered saline (TBS; $20 \mathrm{mM}$ Tris, $500 \mathrm{mM} \mathrm{NaCl}, \mathrm{pH} 7.5$ ), $1 \mathrm{~g}$ fresh $\mathrm{wt} / \mathrm{ml}$. Positive and negative controls were as described for ELISA. Samples were clarified $(5,000 \times g, 1 \mathrm{~min})$, diluted $1: 9$ with sample buffer $(0.5 \mathrm{M}$ Tris-HCL, $\mathrm{pH}$ 6.8 , containing $10 \%$ glycerol, $0.1 \%$ bromophenol blue, $2.0 \%$ sodium dodecyl sulfate [SDS], and $2.0 \% \quad \beta$-mercaptoethanol) and boiled for $5 \mathrm{~min}$. Samples were loaded and electrophoresed as described previously (22). Proteins were electrophoretically transferred to nitrocellulose and Western blotted as described by Fletcher et al. (22). Antisera for LIYV and S. citri were the same as those used for ELISA.

DNA extractions. Extraction of DNA from vascular tissues of crowns or roots of field-collected symptomatic and asymptomatic cucurbit plants was done as described by Kirkpatrick et al. (29) using the method of Dellaporta et al. (11), except that SDS incubations were at room temperature. DNA was extracted from healthy greenhouse-grown cucurbit plants and periwinkle plants infected with aster yellows Oklahoma strain 1 (AYOC-1) phytoplasma according to the method of Errampalli et al. (19), and dot blots were made using the method of Kirkpatrick et al. (29).

Dot and Southern blot hybridizations. Dot blot membranes were hybridized with an oligonucleotide probe (WX1), specific for the 16S rRNA of phytoplasmas, which was ${ }^{32} \mathrm{P}$ end-labeled using the $3^{\prime}$ End-All Biosystem (IBI, New Haven, CT) following the manufacturer's instruction. DNA samples for Southern blots for phytoplasma testing were prepared and digested with $E c o$ RI as described by Ausubel et al. (2). Digested DNA was electrophoresed on $0.7 \%$ agarose gels in Tris borate-EDTA (TBE) buffer as described ( $89 \mathrm{mM}$ Tris, 89 $\mathrm{mM}$ boric acid, $20 \mathrm{mM}$ EDTA), and blotted and hybridized at moderate stringency (31). Membranes were hybridized at $42^{\circ} \mathrm{C}$ in $50 \%$ formamide solutions using a pPY6 cloned fragment of the 16s rRNA gene from the Western-X MLO (provided by Bruce Kirkpatrick, University of California, Davis), which was radioactively labeled using random oligoprimers (Prime-aGene, Promega Corp., Madison, WI). Posthybridization washes were of moderate astringency.

Microscopy. Symptomatic and asymptomatic watermelon, cantaloupe, pumpkin, and squash plants were collected from various areas in central Texas and Oklahoma. Vascular tissues were excised from 
the crown area and fixed in formalin/acetic acid/alcohol solution after collection, dehydrated in a tertiary-butyl alcohol series, and embedded in paraffin (40). Sections (8 to $12 \mu \mathrm{m}$ thick) of the tissue were made with a rotary microtome, stained with safranin-fast green stain, and photographed with a Zeiss microscope fitted with a 35 mm camera.

For transmission electron microscopy (TEM), the phloem was excised from the crown area and cut into approximately 1by $3-\mathrm{mm}$ sections. The tissue was fixed in $2 \%$ glutaraldehyde in $0.1 \mathrm{M}$ potassium phosphate buffer at $\mathrm{pH}$ 7.0. The samples were subsequently fixed overnight in $1 \%$ $\mathrm{OsO}_{4}$ in $0.1 \mathrm{M} \mathrm{KPO}_{4}$ and $0.05 \mathrm{M}$ K-ferricyanide (16) in $0.5 \mathrm{M}$ sucrose, dehydrated in graded series of ethyl alcohol, transferred into propylene oxide, and embedded in Araldite 502-EMBED 812 embedding medium (33). Ultrathin sections were poststained with uranyl acetate in alcohol followed by Reynold's lead citrate (39). Sam-
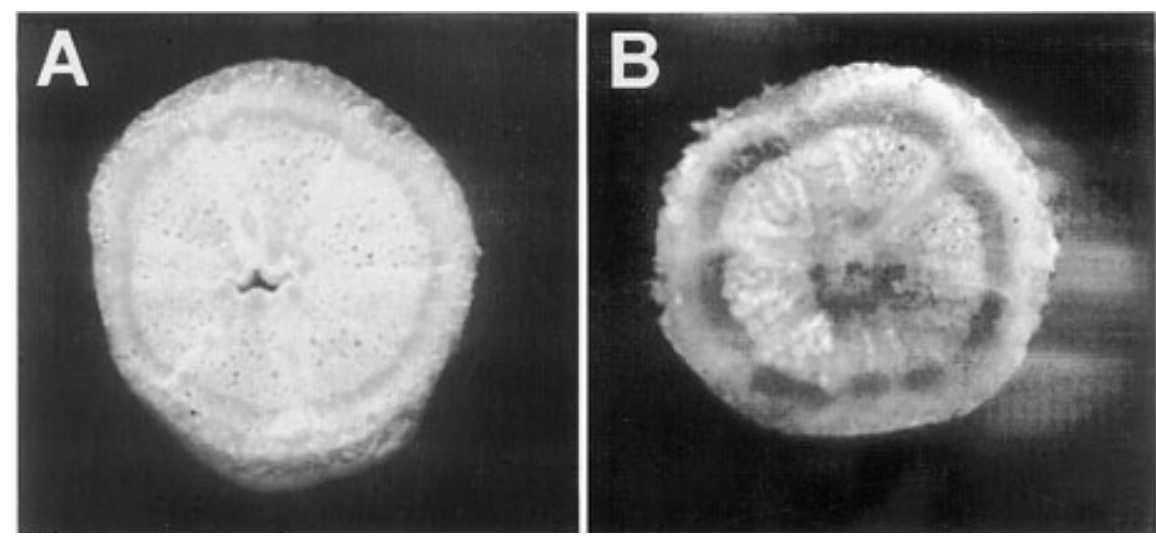

Fig. 1. Cross-section of watermelon crown showing (A) clear translucent appearance in phloem of asymptomatic plant and (B) honey-brown discoloration of interior and exterior phloem of yellow vine diseased plant. ples were examined using a Zeiss transmission electron microscope at $60 \mathrm{kV}$ and photographed on Kodak Electron Microscope Film 4489 (ESTAR thick base).

Samples for scanning electron microscopy (SEM) were taken as described for the histology and TEM. Tissue sections were fixed in $2 \%$ glutaraldehyde in $0.2 \mathrm{M}$ sodium phosphate buffer ( $\mathrm{pH} 7.4$ ), dehydrated in a graded series of ethyl alcohol solutions from 20 to $100 \%$, and dried in Peldri IITM (Ted Pella, Inc., Redding, CA) as an alternative to critical point drying. The samples were coated with gold-palladium using a Hummer ion-sputter coater (Technics, Inc., Alexandria, VA), and examined and photographed using a JEOL 6400 at $15 \mathrm{kV}$ on Ilford Film HP 5 Plus negatives.

\section{RESULTS}

Symptomology. Symptoms in squash and pumpkin normally begin to appear about 7 to 10 days prior to harvest and include a general and rapid yellowing of the leaves over a 3- to 4-day period, followed by a gradual decline of the vine. Terminal leaves tend to stand in vertical position, exhibiting inward curling of the leaf perimeter, and do not expand properly. The older leaves develop a blighted or scorched appearance, whereas the terminal leaves often remain alive, but slightly yellow. Immature plants, exhibiting no yellowing, may wilt and completely collapse in 1 day. No symptoms are associated with the fruit or flowers. In the early stages of disease development, the phloem area in the primary root and crown is slightly discolored, exhibiting a golden to honeybrown appearance. As the disease progresses, the root system deteriorates rapidly and is presumably invaded by secondary microorganisms.

Symptoms in watermelon are similar to those observed on squash and pumpkin, except that fruit on affected watermelon vines become chlorotic soon after disease onset and are thus unmarketable. Symptoms generally appear about 10 to 14 days prior to harvest, with all leaves turning yellow within 3 to 4 days. As with squash, some plants do not turn yellow but rapidly collapse in 1 day. These plants are generally immature and just beginning to establish a good canopy. Leaves on affected plants gradually die, giving the plant a blighted or scorched appearance. Leaves on the stem terminals (approximately 50 $\mathrm{cm})$ do not expand properly, exhibit an inward curling around the leaf perimeter, orient in a vertical position on shortened internodes, and often remain alive for an extended period of time. Root rot is associated with the later stage of disease development, presumably due to invasion by secondary microorganisms. There also is a more intense honey-brown discoloration of

Table 1. Summary of assay results for detection of prokaryotic and viral causes of cucurbit yellow vine

\begin{tabular}{|c|c|c|c|c|c|c|c|c|c|}
\hline \multirow[b]{3}{*}{ Assay $^{a}$} & \multirow[b]{3}{*}{ Yellow vine symptoms ${ }^{b}$} & \multicolumn{8}{|c|}{ Assay Results } \\
\hline & & \multicolumn{2}{|c|}{ Watermelon } & \multicolumn{2}{|c|}{ Cantaloupe } & \multicolumn{2}{|c|}{ Squash } & \multicolumn{2}{|c|}{ Pumpkin } \\
\hline & & $+^{\mathrm{c}}$ & - & + & - & + & - & + & - \\
\hline \multirow[t]{2}{*}{ Dienes' stain } & + & 45 & 14 & 5 & 0 & 8 & 2 & 5 & 2 \\
\hline & - & 1 & 16 & 0 & 2 & 0 & 3 & 0 & 2 \\
\hline \multirow{2}{*}{ ELISA (BCTV) } & + & 13 & 24 & nt & $\mathrm{nt}$ & nt & nt & nt & $\mathrm{nt}$ \\
\hline & - & 1 & 8 & nt & $\mathrm{nt}$ & nt & nt & nt & $\mathrm{nt}$ \\
\hline \multirow[t]{2}{*}{ ELISA (LIYV) } & + & 3 & 1 & 1 & 0 & nt & $\mathrm{nt}$ & nt & $\mathrm{nt}$ \\
\hline & - & 0 & 1 & 0 & 1 & $\mathrm{nt}$ & nt & nt & $\mathrm{nt}$ \\
\hline \multirow[t]{2}{*}{ ELISA (Spiroplasma) } & + & 2 & 13 & 0 & 2 & 4 & 0 & nt & $\mathrm{nt}$ \\
\hline & - & 1 & 8 & 0 & 2 & 0 & 2 & $\mathrm{nt}$ & nt \\
\hline \multirow[t]{2}{*}{ Western blot (LIYV) } & + & 0 & 9 & 0 & 1 & nt & nt & nt & $\mathrm{nt}$ \\
\hline & - & 0 & 2 & 0 & 1 & $\mathrm{nt}$ & nt & nt & nt \\
\hline \multirow[t]{2}{*}{ Western blot (S. citri) } & + & 0 & 3 & nt & $\mathrm{nt}$ & 0 & 1 & nt & $\mathrm{nt}$ \\
\hline & - & 0 & 2 & nt & nt & 0 & 1 & nt & nt \\
\hline \multirow[t]{2}{*}{ Dot blot (Phytoplasmas) } & + & 10 & 0 & nt & nt & $\mathrm{nt}$ & nt & nt & $\mathrm{nt}$ \\
\hline & - & 2 & 0 & nt & $\mathrm{nt}$ & nt & nt & nt & $\mathrm{nt}$ \\
\hline \multirow[t]{2}{*}{ Transmission EM } & + & 20 & 0 & 7 & 0 & 4 & 0 & $\mathrm{nt}$ & nt \\
\hline & - & 0 & 15 & 0 & 5 & 0 & 4 & nt & $\mathrm{nt}$ \\
\hline
\end{tabular}

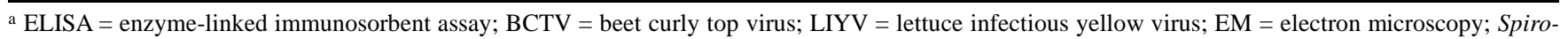
plasma spp. $=S$. citri and $S$. kunkelii.

$\mathrm{b}+=$ symptomatic, $-=$ asymptomatic for yellow vine based on light microscopy.

$\mathrm{c}+=$ positive,$-=$ negative, $\mathrm{nt}=$ not tested . 
the phloem (Fig. 1) compared to squash and pumpkin. The symptomology on cantaloupe is identical to that observed in watermelon, except that the vines die more quickly.

Fungal isolations and pathogenicity. Fungi in the genus Fusarium were most frequently isolated from affected plants. $F$. solani, $F$. semitectum, $F$. oxysporum, and $F$. equiseti were most often isolated from both symptomatic and asymptomatic plants. Other fungi frequently isolated were Macrophomina phaseolina (Tassi) Goidanich, Phoma terrestris E. M. Hans., Pythium spp., Rhizopycnis vagum D. F. Farr, Rhizoctonia solani Kühn, and Plectosporium tabacinum (Van Beyma) M. E. Palm, W. Gams \& H. Nirenberg. None of the fungi were consistently associated with field symptoms of yellow vine in cantaloupe and watermelon. Numerous $F$. oxysporum isolates were inoculated onto watermelon and cantaloupe genotypes for race differentiation. Most of the watermelon and cantaloupe isolates were nonpathogenic. Pathogenic watermelon isolates were predominantly race 1 , occasionally race 0 , and rarely race 2 . The cantaloupe isolates of $F$. oxysporum were nonpathogenic, with the exception that race 2 was found in 3 of the 29 isolates tested. The remaining Fusarium spp. were either non-pathogenic or caused root rot but did not cause yellow vine symptoms or produce phloem discoloration.

Isolation of prokaryotes. Numerous bacteria were isolated from each of the cucurbit species, but there was no consistent correlation with any cultivable bacterium from symptomatic plants. Using fatty acid profiles, the bacteria were identified as Acinetobacter baumannii, Agrobacterium radiobacter, Arthrobacter pascens, Bacillus megaterium, B. polymyxa, $B$. pumilus, Citrobacter diversus, Enterobacter agglomerans, E. cancerogenus, E. cloacae, E. intermedius, Erwinia carotovora, E. herbicola, E. uredovora, Flavobacterium indologenes, Klebsiella planticola, K. pneumoniae, Kluyvera cryocrescens, Pseudomonas chloroaphis, P. fluorescens, $P$. putida, and Stenotrophomonas maltophilia. Inoculations with representative bacterial isolates failed to reproduce symptoms of yellow vine or phloem discoloration in watermelon and squash plants. None of the symptomatic or asymptomatic watermelon plants or squash plants yielded spiroplasmas in culture, although they were recovered from control periwinkles inoculated with $S$. citri.

Dienes' stain. Dienes' stain has been reported to identify plant tissues infected with mollicutes (spiroplasmas and phytoplasmas). There were more positive samples among yellow vine symptomatic plants than among asymptomatic plants in each cucurbit species, but there were also symptomatic plants that did not stain and asymptomatic plants that did stain (Table
1). Among BCTV-infected samples, pepper and sugar beet were negative, but bean stem sections showed distinctive, localized blue staining in the phloem, indistinguishable from the typical Dienes' reaction seen with mollicute infection. Healthy bean controls were negative.

Transmission experiments. None of the cucurbit plants inoculated mechanically or with the artist air brush, using sap from symptomatic watermelon plants, developed symptoms suggestive of yellow vine. Cross-sections of the crowns of inoculated plants exhibited no phloem discoloration.

Dodder died within 7 to 10 days on yellow vine-affected watermelon plants, but became established and grew vigorously on asymptomatic watermelon plants. The dodder was removed from periwinkle plants when they were placed in the greenhouse. After 60 days in the greenhouse, no disease symptoms appeared on dodderexposed periwinkle plants. Each periwinkle plant was excised about $10 \mathrm{~cm}$ above soil line to examine the phloem. Thin sections were cut and examined using a light microscope for phloem discoloration. Only 1 of the 25 periwinkle plants exposed to dodder from symptomatic watermelon exhibited phloem discoloration, while none of the periwinkle plants exposed to dodder from asymptomatic plants did so. The sin-
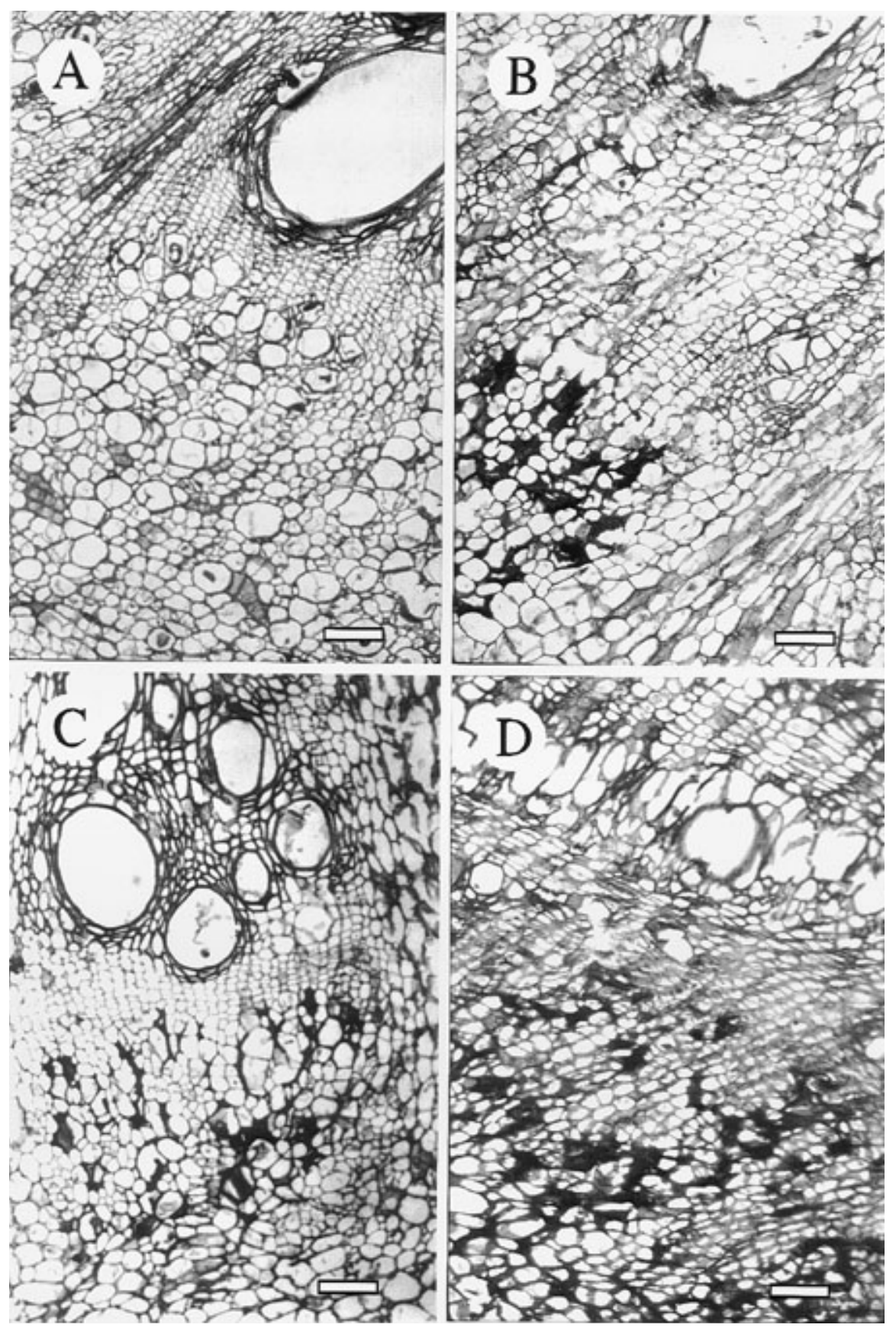

Fig. 2. Light micrographs of transverse section of the crown area of cucurbits. (A) Healthy watermelon; (B, C, and $\mathbf{D})$ the accumulation of stain (safranin) in the phloem tissue of yellow vine-affected watermelon, cantaloupe, and squash, respectively (scale bars $=100 \mu \mathrm{m}$ ). 
gle plant exhibiting phloem discoloration did not produce new growth and died within a few days. All of the remaining plants produced new growth and were vigorous for an additional 30 days.

None of the plants exposed to either field-collected leafhoppers or to insects from laboratory-reared colonies of $C$. tenellus and $M$. quadrilineatus, allowed to feed on symptomatic plants, developed symptoms of yellow vine.

Serological and molecular detection assays. Results of ELISA, Western blotting, dot blotting, and Southern blotting are shown in Table 1. ELISA results from tests with BCTV, LIYV, S. citri, and S. kunkelii antisera were ambiguous but showed no consistent relationship of these pathogens with yellow vine. Western blots, conducted in an attempt to clarify the ELISA results, also gave no indication that symptomatic cucurbit plants were infected with LIYV or with either spiroplasma. Results of the dot blot hybridizations for detection of phytoplasmas also were inconsistent, but failed to confirm phytoplasma involvement with yellow vine. Dot blots for BCTV and whitefly-transmitted geminiviruses were negative. In Southern blots, no novel bands were observed in the restriction length polymorphisms on autoradiographs of symptomatic cucurbit plants probed with pPY6, compared to the patterns in asymptomatic plants. Appropriate positive and negative controls included in each of these experiments gave expected results.

Microscopy. Unstained hand-cut thin sections from the crown of watermelon, cantaloupe, squash, and pumpkin showed the honey-brown discoloration in the phloem area, making diagnosis rapid and easy. However, the discoloration in squash and pumpkin was less intense than that in melons, making the diagnosis slightly more difficult in these plant species. Histological examinations of affected watermelon, cantaloupe, squash, and pumpkin showed similar patterns of strong staining with safranin in the phloem area of all affected plants (Fig. 2). Staining was absent in the phloem of asymptomatic plants.
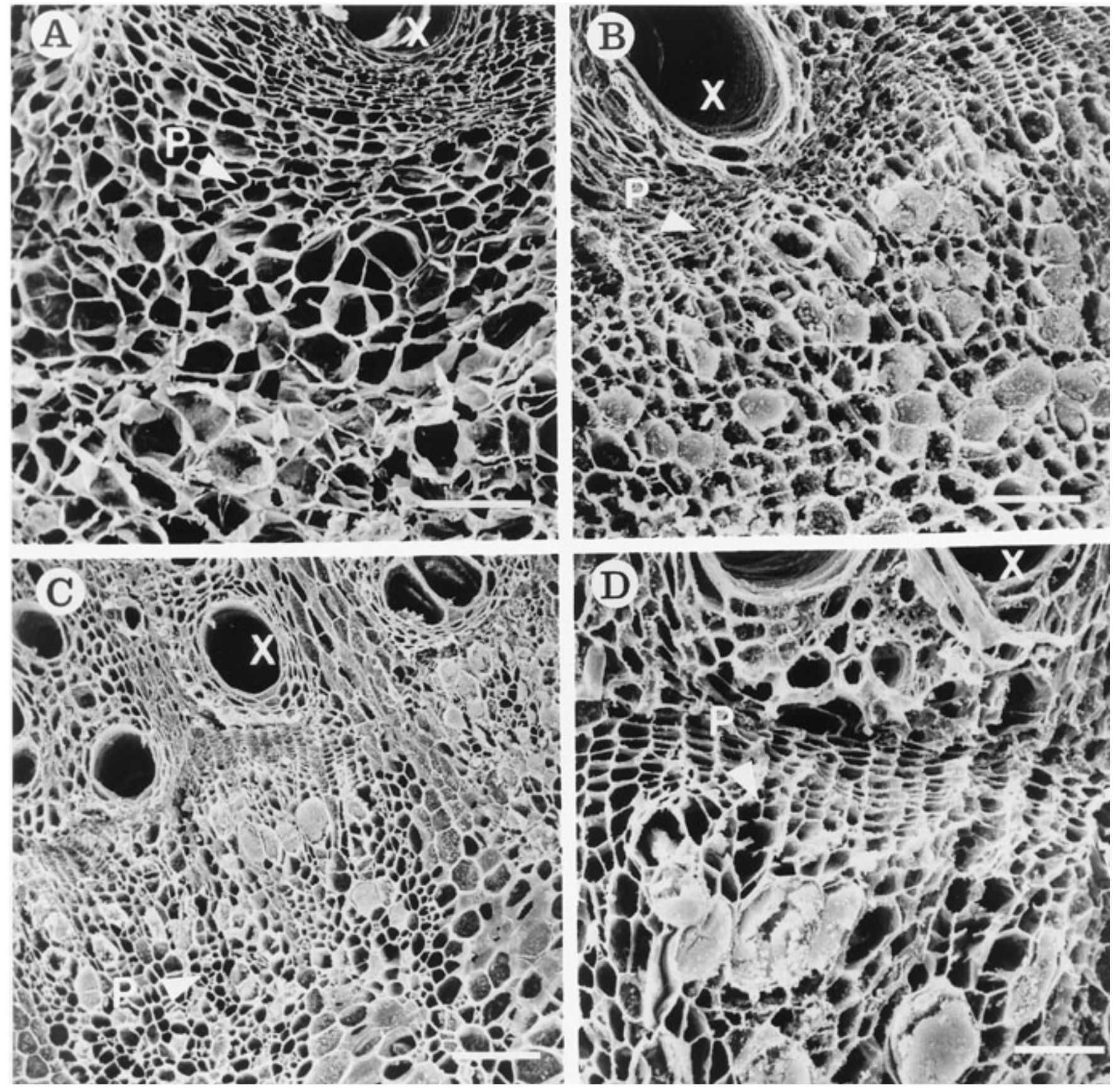

Fig. 3. Scanning electron micrograph of cucurbits illustrating the phloem area of $(\mathbf{A})$ healthy watermelon $(\mathrm{scale}$ bar $=100 \mu \mathrm{m})$ and $(\mathbf{B})$ yellow vine-affected watermelon $($ scale $b a r=100 \mu \mathrm{m}),($ C $)$ cantaloupe $($ scale bar $=200 \mu \mathrm{m})$, and $(\mathbf{D})$ squash $($ scale bar $=100 \mu \mathrm{m})$, respectively. 
SEM examination revealed extensive plugging of the sieve elements (Fig. 3) in symptomatic cantaloupe, watermelon, and squash plants. Bacteria were not observed using SEM, presumably because they were embedded in a homogeneous matrix that was clogging the phloem sieve tube elements. The surrounding tissues appeared normal and the xylem vessels were clear and unobstructed.

TEM revealed the presence of bacteria in the phloem sieve tubes of all 20 symptomatic watermelon (Fig. 4A and B), 7 cantaloupe (Fig. 4C and D), and 4 squash plants (Fig. 4E) that were examined. Bacteria were never observed in sieve tubes of similar numbers of asymptomatic samples. The bacteria exhibited a triple-layered cell envelope, 10 to $40 \mathrm{~nm}$ in thickness, consisting of double walls and an inner translucent zone, features typical of bacteriumlike organisms (BLOs; 15). The bacteria were approximately 0.25 to $0.5 \mu \mathrm{m}$ in width and ranged from 1.0 to $3.0 \mu \mathrm{m}$ in length. Bacteria were observed only in phloem sieve tubes. Cell wall-less, pleomorphic, or spiral forms typical of phytoplasmas and spiroplasmas, respectively, were never observed, nor were virus particles or virus inclusion bodies present in either symptomatic or asymptomatic samples. Many of the sieve tube elements appeared to have a granulated appearance, perhaps due to the plugging material observed in SEM.

\section{DISCUSSION}

In the last 10 to 15 years, there have been several reports of new vine decline diseases of watermelon and cantaloupe $(5,6)$. Here, we report a new cucurbit vine decline in Oklahoma and Texas. In our initial investigations, we followed general procedures of fungal and bacterial isolations appropriate for investigation of an unknown disease. In the present study, hundreds of isolations from yellow vineaffected cantaloupe, watermelon, and squash failed to show a consistent association of any microorganism with the disease. Inoculation of cucurbit test plants with numerous different fungi and bacteria failed to reproduce yellow vine symptoms, including foliar yellowing or phloem discoloration (data not shown). Although many of the microorganisms isolated are capable of being primary pathogens, they were routinely isolated from symptomatic and asymptomatic plants.

Because of the obvious phloem damage associated with yellow vine, our failure to consistently associate any cultivable fungus or bacterium with diseased plants, and a previous report (7) that insects may be associated with yellow vine of squash and pumpkin, research efforts were directed to the possibility of the involvement of an unusual, fastidious prokaryote or virus. Ivanoff and Ewart (27) had reported the presence of aster yellows, now known to be caused by a leafhopper transmitted phytoplasma, on cucurbits in the Winter Garden region of Texas. Dienes' stain, reported to be specific for the presence of mollicutes in plant phloem tissue (17), gave ambiguous results with diseased and healthy cucurbit samples in this study (Table 1). However, none of our subsequent tests (isolation attempts, ELISA, Western blots, DNA hybridizations for phytoplasmas, or electron microscopy) confirmed the presence of a mollicute in affected tissues. The positive Dienes' stain reaction in plants exhibiting phloem discoloration suggests that this stain may not be completely mollicute-specific.

The possibility that cucurbit yellow vine was caused by a known phloem-limited virus, such as BCTV or whitefly-transmitted geminivirus (including LIYV) was then investigated. Halliwell and Johnson (25), in 1992, reported LIYV on cantaloupe and honeydew melons in north central Texas, watermelon in central Texas, and squash and cushaw along the upper Gulf Coast. However, in numerous surveys in central Texas and Oklahoma from 1991 to the present, whiteflies have never been observed during the growing season (S. Pair and B. Bruton, personal observation). As with the mollicutes, a range of seriological and molecular detection methods failed to confirm the presence of any of these agents in diseased plants. In addition, dsRNA was never detected in spite of many attempts (R. Valverde, personal communication). The erratic ELISA results with both viruses and mollicutes suggests the presence of chemical interference producing false positives with cucurbit samples under our conditions.

The presence of bacteria, observed by electron microscopy in the phloem of yellow vine-affected cantaloupe, watermelon, and squash plants, and their consistent absence in phloem of asymptomatic plants, suggests a causal role for a phloem-limited bacterium in the yellow vine syndrome. The failure to detect disease-specific bands with the pPY6 probe, which reacts with the $16 \mathrm{~S}$ rRNA of most prokaryotes, may be due to the low titer of the bacteria within the plant phloem. Lafleche and Bové (30) were the first to recognize that a group of phloem-limited plant pathogens, with an outer envelope more complex than those of the wall-less prokaryotes, might represent a new class of plant pathogen. Davis et al. (15) discussed several structural features common to the phloem-limited BLOs: the organisms are elongate, have ribosomal and diffuse nuclear areas characteristic of prokaryotic cells, and are bounded by a "wavy" envelope that consists, in part, of two single membranes ( $\approx 8 \mathrm{~nm}$ wide), a cell wall $(20$ to $32 \mathrm{~nm}$ ) with no apparent Rlayer, and with similarities to that of gramnegative bacteria. There are more than 20 plant diseases associated with or known to be caused by phloem-limited BLOs with dimensions ranging from 0.25 to 0.5 by 0.8 to $4.0 \mu \mathrm{m}(13,15,23,26,28,35,44)$. Hopkins (26), in a review, noted that phloem-limited BLO diseases produce symptoms characteristic of the yellows type, usually including stunting, yellowing of young leaves, leaf curling and twisting, uneven expansion of leaves, virescence of flower petals, and often premature death of the plant. Symptoms of cucurbit yellow vine exhibit all these characteristics, with the exception of virescence of flower petals, and essentially all leaves turn yellow. It is interesting to note that in both bunchy top disease of papaya (13) and yellow vine of squash (7), a tuft of small leaves are all that remain in the later stage of disease. In watermelon, only the terminal $30 \mathrm{~cm}$ or so of the stem remains alive in the latter stage of yellow vine development (9).

Many phloem-limited plant pathogens, both viruses and prokaryotes, are transmitted by phloem-feeding insects. Pair et al. (36), in an attempt to transmit yellow vine to squash, reported negative results using field-collected squash bugs, aphids, leafhoppers, and cucumber beetles. Similarly, the insect transmission attempts reported here were negative under the conditions of our studies. However, Bruton et al. (7) reported a significantly lower incidence of yellow vine in squash plots receiving weekly applications of cypermethrin insecticide as compared to the non-treated plots. Yellow vine appears to be a "simple interest" disease (45) that spreads to cucurbits from outside sources with little, if any, within-field spread. Duthie et al. (18) reported that the disease was aggregated in small pockets. Cucurbits planted directly adjacent to an existing affected field may have little or no yellow vine. One plausible explanation of these observations is that a putative insect vector, carrying the yellow vine agent from an outside source, very quickly loses the ability to inoculate new plants and is unable to acquire the bacterium from cucurbits to transmit to other cucurbits. The distribution of the bacterium within a cucurbit plant is unknown, but the titer in the foliage may be insufficient for insect acquisition.

Yellow vine appears to be geographically restricted to east, central, and northcentral Texas and Oklahoma $(8,9)$, a geographic pattern that corresponds to a region known as the Cross Timbers Vegetational Area, which is dominated by various oak, elm, pecan, mesquite, and cedar (1). In 1993 and 1994, yellow vine was rarely observed in Oklahoma, although some disease occurred in central Texas (9). In 1995 and 1996, yellow vine caused greater than $50 \%$ losses in some fields of watermelon in southwestern Oklahoma. Some fields in southwestern Oklahoma and East Texas had yellow vine in nearly $100 \%$ of the plants in 1997 (B. Bruton and S. Pair, unpublished data). Why yellow vine caused substantial losses in squash and 

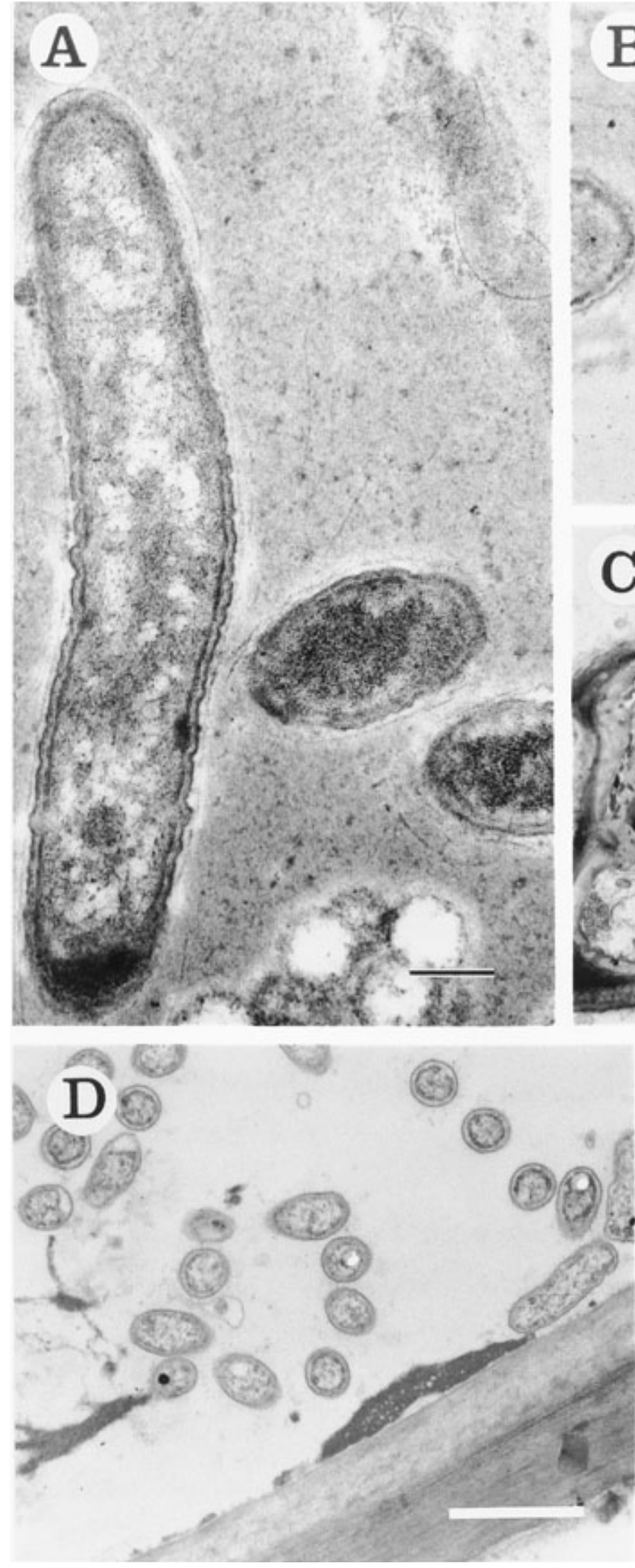
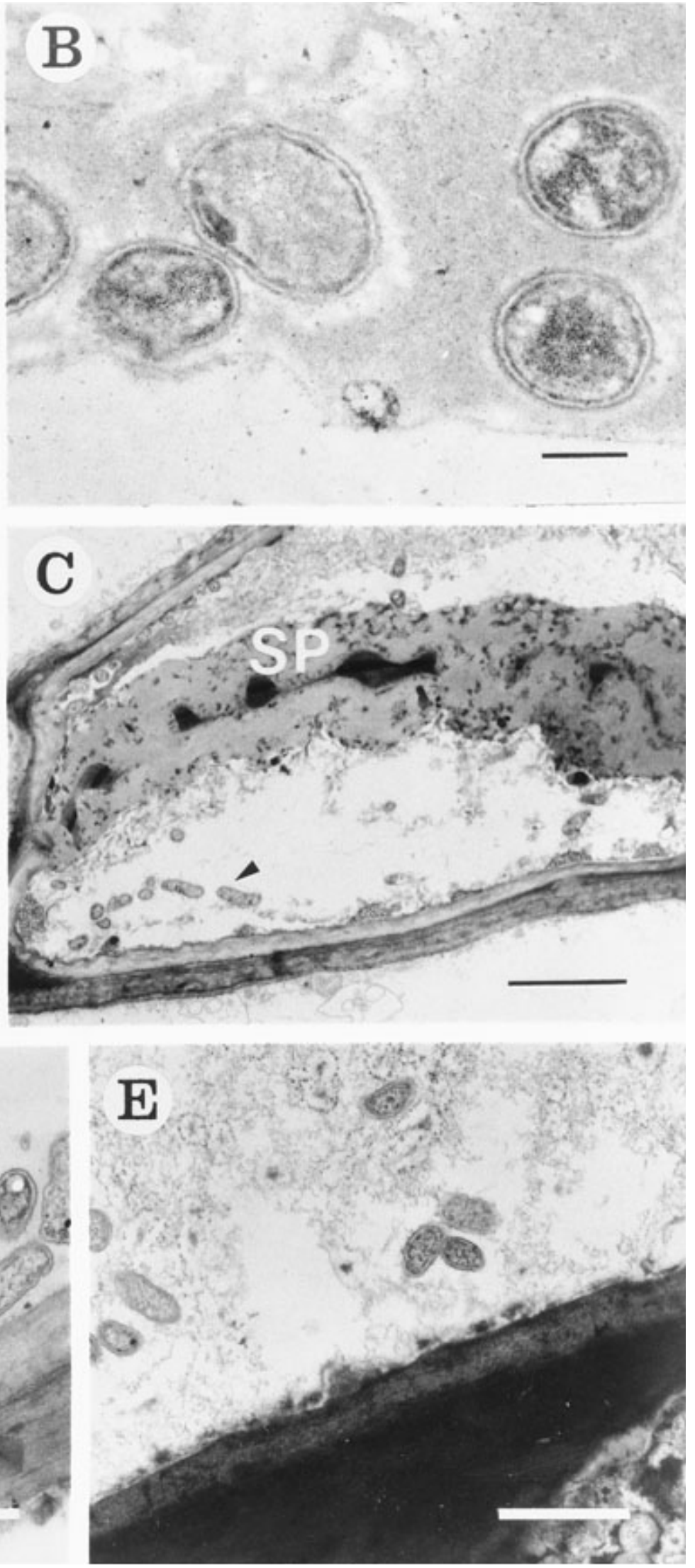

Fig. 4. Transmission electron microscopy of cucurbits affected by yellow vine. (A) Elongate bacterium in the phloem sieve tube element of watermelon with characteristic double cell wall and rippled outer wall (scale bar $=0.25 \mu \mathrm{m})$; and $(\mathbf{B})$ the small, round-shaped bacteria $(\mathrm{scale}$ bar $=0.25 \mu \mathrm{m})$. $(\mathbf{C})$ Sieve plate (SP) and bacteria (arrow) in phloem sieve tube element of cantaloupe (scale bar $=2.5 \mu \mathrm{m})$; and $(\mathbf{D})$ round and elongate bacteria $(\mathrm{scale}$ bar $=1 \mu \mathrm{m})$. (E) Bacteria in the phloem sieve tube element of squash (scale bar $=1 \mu \mathrm{m})$. 
pumpkin (7), but not cantaloupe and watermelon, from 1988 through 1990, and in 1991 caused severe losses to watermelon and cantaloupe, is still unclear. In a limited-field host range study in 1989, consisting of cantaloupe, watermelon, squash, and cucumber, squash was the only cucurbit to develop yellow vine (B. Bruton and B. Cartwright, unpublished data). Yellow vine has never been observed in cucumber $(8,9)$.

In a recent review, Purcell and Hopkins (38) noted that localized, nonsystemic infections by bacteria may be very common in many plant species. The genesis, by mutation or recombination, of a bacterial strain capable of inducing disease in cucurbits is therefore possible. With the importation of many plant species from all parts of the world in recent years, the introduction of new bacteria is a distinct possibility. It is also possible that expression of yellow vine symptoms in different cucurbit crops may be due to similar but genetically divergent organisms. For example, the BLO causing citrus greening disease (Asian strain) is transmitted by the psyllid Diaphorina citri (4), while the African strain is transmitted by the psyllid Trioza erytreae (41). The Asian strain is heat-tolerant, with symptoms occurring at temperatures in excess of $30^{\circ} \mathrm{C}$, whereas the African strain is more heat-sensitive, producing no symptoms above $30^{\circ} \mathrm{C}$ (4). Sequence comparisons of the African and Asian BLO operons indicated that they represent different species within the proposed genus Liberobacter (37).

The work described here demonstrates the association of a phloem-limited bacterium with yellow vine disease of cucurbits. Additional support for a bacterial etiology of yellow vine comes from a parallel study in our laboratories, in which Avila et al. (3) developed yellow vine-specific primers for use in the polymerase chain reaction (PCR). PCR consistently amplified a specific band from yellow vine-diseased cucurbit plants, but not from asymptomatic plants. The specific genomic sequences amplified using these primers, when compared with known sequences in gene databanks, were shown to be those of a gamma proteobacterium. Further characterization of this phloem-limited bacterium will be needed to facilitate completion of the steps of Koch's postulates for yellow vine of cucurbits, resolution of the question of whether this organism comprises a homogeneous or heterogeneous population within the Cross-Timbers region of Oklahoma and Texas, and elucidation of critical elements of the disease epidemiology.

\section{ACKNOWLEDGMENTS}

We thank Anthony Dillard, Diann Baze, and Bill Anderson for technical assistance; P. Thomas, J. Brown, R. Valverde, R. Gilbertson, R. Creamer, R. Stall, L. Barnes, J. Pennington, G. Baker, J. Jacobs, and J. Sherwood for assistance in diagnostic procedures and provision of antiserum; and
J. Damicone, B. Whitney, L. Nowlin, and J. Farley for assistance with plant maintenance and collection.

\section{LITERATURE CITED}

1. Austin, M. E. 1965. Land Resource Regions and Major Land Resource Areas of the United States. U. S. Dep. Agric. Soil Conservation Serv. Handb. 296.

2. Ausubal, F. M., Brent, R., Kingston, R. E., Moore, D. D., Smith, J. A., Seidman, J. G., and Struhl, K. 1987. Current Protocols in Molecular Biology. John Wiley \& Sons Inc., New York.

3. Avila, F. J., Bruton, B. D., Fletcher, J., Sherwood, J. L., Pair, S. D., and Melcher, U. Polymerase chain reaction detection and phylogenetic characterization of an agent associated with yellow vine disease of cucurbits. Phytopathology In press.

4. Bové, J. M., Calavan, E. C., Capoor, S. P., and Schwartz, R. E. 1974. Influence of temperature on symptoms of California stubborn, South Africa greening, Indian citrus decline and Philippines leaf mottling diseases. Pages 12-15 in: Proc. 6th Conf. Int. Org. Citrus Virol. L. G. Weather and M. Cohen, eds.

5. Bruton, B. D. 1996. Chart of diagnostic characteristics of soil-borne diseases of cantaloupe. Page 10. In: Compendium of Cucurbit Diseases. T. A. Zitter, D. L. Hopkins, and C. E. Thomas, eds. American Phytopathological Society, St Paul, MN

6. Bruton, B. D., Amador, J. M., and Miller, M. E. 1988. Atlas of Soilborne Diseases of Melons. Texas Agric. Ext. Serv. Publ., B-1595.

7. Bruton, B. D., Pair, S. D., Popham, T. W., and Cartwright, B. O. Occurrence of yellow vine, a new disease of squash and pumpkin, in relation to insect pests, mulches, and soil fumigation. Subtrop. Plant Sci. 47:53-58.

8. Bruton, B. D., Pair, S. D., and Wann, E. V. 1995. Yellow vine disease of watermelon and cantaloupe in Central Texas and Oklahoma. Pages. 151-159 in: Proc. Cucurbitaceae 94. G. E. Lester and J. R. Dunlap, eds.

9. Bruton, B. D., Pair, S. D., and Wann, E. V. 1995. Yellow vine disease of watermelon and cantaloupe in Texas and Oklahoma. U. S. Dep. Agric. Publ. SCARL 101.

10. Clark, M. F., and Adams, A. N. 1977. Characteristics of the microplate method of enzyme-linked immunosorbent assay for the detection of plant viruses. J. Gen. Virol. 34:475-483.

11. Dallaporta, S. L., Wood, J., and Hicks, J. B. 1983. A plant DNA minipreparation: version II. Plant Mol. Biol. Rep. 1:19-21.

12. Davis, M. J., French, W. J., and Schaad, N. W. 1981. Axenic culture of the bacteria associated with phony disease of peach and plum leaf scald. Curr. Microbiol. 6:309-314.

13. Davis, M. J., Kramer, J. B., Ferwerda, F. H., and Brunner, B. R. 1996. Association of a bacterium and not a phytoplasma with papaya bunchy top disease. Phytopathology 86:102109.

14. Davis, M. J., Purcell, A. H., and Thompson, S.V. 1980. Isolation media for the Pierce's disease bacterium. Phytopathology 70:425429.

15. Davis, M. J., Whitcomb, R. F., and Gillespie, A. G. Jr. 1981. Fastidious bacteria of plant vascular tissue and invertebrates (including so called rickettsia-like bacteria). Pages 21722188 in: The Prokaryotes: A Handbook on Habits, Isolation, and Identification of Bacteria. M. P. Starr, H. Stolp, H. G. Truper, A. Balows, and H. G. Schlegel, eds. SpringerVerlag, Berlin.

16. De Bruijn, W. C. 1973. Glycogen, its chemistry and morphologic appearance in the electron microscope. I. A modified $\mathrm{OsO}_{4}$ fixative which selectively contrasts glycogen. J. Ultrastruct. Res. 42:29.

17. Deely, J., Stevens, W. A., and Fox, R. T. V. 1979. Use of Dienes' stain to detect plant diseases induced by mycoplasmalike organisms. Phytopathology. 69:1169-1171.

18. Duthie, J. A., Bruton, B. D., and Pair, S. D. 1993. Abundance and spatial aggregation of yellow vine in crops of watermelon and muskmelon. (Abstr.) Phytopathology 83:465.

19. Errampalli, D., Fletcher, J., and Claypool, P. L. 1991. Incidence of aster yellows in carrot and lettuce and characterization of AY mycoplasmalike organism isolates in Oklahoma Plant Dis. 75:579-584.

20. Fletcher, J., and Eastman, C. E. 1984. Translocation and multiplication of Spiroplasma citri in turnip (Brassica rapa). Curr. Microbiol. 11:289-292.

21. Fletcher, J., Schultz, G. A., Davis, R. E. Eastman, C. E., and Goodman, R. M. 1981. Brittle root disease of horseradish: Evidence for an etiological role of Sprioplasma citri. Phytopathology 71:1073-1080.

22. Fletcher, J., Wills, J. W., and Denman, S. E., 1989. Identification of surface proteins of Sprioplasma citri using protease and antibody probes. Curr. Microbiol. 19:383-391.

23. Garnier M., Danel N., and Bové, J. M. 1984 Aetiology of citrus greening disease. S. Villechanoux et al.: Citrus Greening DNA Probes. Ann. Microbiol. (Paris) 135A:169-179.

24. Gussie, J. S., Fletcher, J., and Claypool, P. L. 1995. Movement and multiplication of Spiroplasma kunkelii in corn. Phytopathology 85:1093-1098.

25. Halliwell, R. S., and Johnson, J. D. 1992. Lettuce infectious yellows virus infecting watermelon, cantaloupe, honey dew melon, squash, and cushaw in Texas. Plant Dis. 76:643

26. Hopkins, D. L. 1977. Diseases caused by leafhopper-borne, rickettsia-like bacteria. Annu. Rev. Phytopathol. 17:277-294.

27. Ivanoff, S. S., and Ewart, W. H. 1944. Aster yellows on vegetable crops and weeds in the Winter Garden region of Texas. Plant Dis. Rep. 28:972-977.

28. Jagoueix, S., Bové, J. M., and Garnier, M. 1994. The phloem-limited bacterium of greening disease of citrus is a member of the $\alpha$ subdivision of the Proteobacteria. Int. J. Syst. Bacteriol. 44:379-386.

29. Kirkpatrick, B. C., Stenger, D. C., Morris, T. J., and Purcell, A. H. 1987. Cloning and detection of DNA from a nonculturable plant pathogenic mycoplasma-like organism. Science 238:197-200.

30. Lafléche, D., and Bové, J. M. 1970. Mycoplasmes dans les agrumes atteints de greening. de stubborn ou de maladies similaires. Fruits 25:455-465.

31. Maniatis, T., Fritsch, E. F., and Sambrook, J. 1982. Molecular Cloning: A Laboratory Manual. Cold Spring Harbor Laboratory, Cold Spring Harbor, NY.

32. Martyn, R. D., and Bruton, B. D. 1989. An initial survey of the United States for races of Fusarium oxysporum f. sp. niveum. HortScience 24:696-698.

33. Mollenhauer, H. H. 1964. Plastic embedding mixtures for use in electron microscopy. Stain Technol. 39:111-114.

34. Nirenberg, H. I. 1976. Untersuchungen über die morphologische und biologische Differenzierung in der Fusarium-Sektion Liseolo. Mitt. Biol. Bundesanst. Land Forstwirtsch Berlin-Dahlem 169:1-117.

35. Nourrisseau, J. G., Lansac, M., and Garnier, M. 1993. Marginal chlorosis, a new disease of strawberries associated with a bacterium-like organism. Plant Dis. 77:1055-1059.

36. Pair, S. D., Bruton, B. D., Cartwright, B., and 
Duthie, J. 1993. Status of search for insect vectors of yellow vine in cucurbits. Proc. 12th. Annu. Hortic. Ind. Conf. 12:149-151.

37. Planet, P., Jagoueix, S., Bove, J. M., and Garnier, M. 1995. Detection and characterization of the African citrus greening liberobacter by amplification, cloning, and sequencing of the rplKAJL-rpoBC operon. Curr. Microbiol. 30:137-141

38. Purcell, A. H., and Hopkins, D. L. 1996. Fastidious xylem-limited bacterial plant pathogens. Annu. Rev. Phytopathol. 34:131151.
39. Reynolds, E. S. 1963. The use of lead citrate at high $\mathrm{pH}$ as an electron-opaque stain in electron microscopy. J. Cell Biol. 17:208-212.

40. Sass, J. E. 1958. Botanical Microtechnique. 3rd ed. Iowa State College Press, Ames.

41. Schwarz, R. E., and Green, G. C., 1970. Citrus greening and the citrus psyllid Trioza erytreae, a temperature dependant agent-vector complex. Z. Pflanzenkr. Pflanzenschutz 79:490-493.

42. Toler, R. W., and Hebert, T. T. 1965. Transmission of soil borne oat mosaic virus increased by artist's airbrush inoculation. Plant
Dis. Rep. 49:553-555.

43. Wells, J. M., Raju, B. C., Hung, H-Y., Weisberg, W. G., Mandelco-Paul, L. et al. 1987. Xylella fastidiosa: a new-genus new-species Gram-negative xylem-limited fastidious plant bacteria related to Xanthomonas spp. Int. J. Syst. Bacteriol. 37:136-143.

44. Windsor, I. M., and Black, L. M. 1973. Evidence that clover club leaf is caused by a rickettsia-like organism. Phytopathology 63:1139-1148.

45. Yarwood, C. E. 1970. Man-made plant diseases. Science 168:218-220. 